\title{
PROGRAM KEMITRAAN MASYARAKAT MELALUI PENERAPAN TEKNOLOGI PENGASAPAN IKAN TERBANG DI KELURAHAN MOSSO, KABUPATEN MAJENE, PROVINSI SULAWESI BARAT
}

\author{
Reski Fitriah"1), Muhammad Nur2), Muhammad Nur Ihsan ${ }^{1)}$, Apriansyah²), \\ Nur Indah Sari Arbit'2), Ady Jufri'), Tenriware ${ }^{1)}$, Admi Athirah ${ }^{4)}$ \\ 1)Program Studi Perikanan Tangkap, Universitas Sulawesi Barat, Mamuju, Sulawesi Barat, Indonesia \\ 2)Program Studi Akuakultur, Universitas Sulawesi Barat, Mamuju, Sulawesi Barat, Indonesia \\ ${ }^{3)}$ Program Studi Teknik Sipil, Universitas Sulawesi Barat, Mamuju, Sulawesi Barat, Indonesia \\ ${ }^{4)}$ Balai Riset Perikanan Budidaya Air Payau dan Penyuluhan Perikanan, Makasar, Sulawesi elatan, Indonesia
}

Corresponding author : Muhammad Nur

E-mail : muhammadnur@unsulbar.ac.id

Diterima 09 November 2020, Direvisi 13 November 2020, Disetujui 14 November 2020

\begin{abstract}
ABSTRAK
Ikan terbang merupakan salah satu sumberdaya perikanan yang melimpah dan memiliki nilai sosial ekonomi cukup penting karena salah satunya dijadikan sebagai usaha pengasapan ikan di Provinsi Sulawesi Barat. Program Kemitraan Masyarakat Melalui Penerapan Teknologi Pengasapan Ikan Terbang Di Kelurahan Mosso, Kabupaten Majene, Provinsi Sulawesi Barat, bertujuan untuk meningkatkan kemampuan dan keterampilan masyarakat tentang cara produksi ikan asap yang baik. Kegiatan ini dilaksanakan pada bulan Juni 2020 di Kelurahan Mosso, Kecamatan Sendana, Kabupaten Majene, Provinsi Sulawesi Barat. Mitra kelompok yang menjadi sasaran utama pengabdian ini yaitu kelompok usaha pengasapan ikan terbang "Siamasei Lestari". Metode yang digunakan pada kegiatan pengabdian ini Penyuluhan dan praktek cara produksi ikan asap yang baik serta introduksi teknologi alat pengasapan ikan. Hasil yang dicapai dari kegiatan ini antara lain meningkatnya kemampuan dan keterampilan masyarakat tentang cara produksi ikan asap yang baik dan adanya alat pengasapan ikan yang dapat digunakan untuk pengembangan usaha mitra program kemitraan masyarakat. Beberapa keuntungan dari penggunaan alat pengasapan ikan antara lain efisiensi penggunaan asap sehingga produk cepat matang, kualitas yang seragam dan warna yang lebih menarik, kuantitas produk lebih banyak, produk akhir yang lebih higienis, menghemat biaya produksi karena efisiensi bahan bakar yang digunakan optimal dan produk akhir yang lebih higienis karena proses produksi tidak terkontaminasi.
\end{abstract}

Kata kunci: Ikan terbang; pengasapan; program kemitraan masyarakat; sulawesi barat; teknologi

\begin{abstract}
Flying fish is one of the abundant fisheries resources and has quite important socio-economic value because one of them is used as a fish smoking business in West Sulawesi Province. The community development program through the Application of Flying Fish Smoking Technology in Mosso Village, Majene Regency, West Sulawesi Province, the aims to improve the capacity and skills of the community on good smoked fish production methods. This activity was carried out in June 2020 in Mosso Village, Sendana District, Majene Regency, West Sulawesi Province. The group partner who is the main target of this service is the flying fish smoking business group "Siamasei Lestari". The method used in this service activity provides counseling and practice of good smoked fish production methods as well as the introduction of smoking equipment technology. The results that were achieved from this activity included the improvement of the community's abilities and skills on how to produce smoked fish properly and the existence of a fish smoker that can be used for business development of community partnership program partners. Some of the advantages of using fish smoking equipment include the efficient use of smoke so that the product ripens quickly, uniform quality and more attractive color, more product quantity, more hygienic final products, saving production costs due to optimal fuel efficiency and final product. which is more hygienic because the production process is not contaminated.
\end{abstract}

Keywords: flying fish; smoked; community development program; west sulawesi; technology

\section{PENDAHULUAN}

Pengasapan ikan merupakan salah satu bentuk pengolahan hasil perikanan yang telah lama dilakukan oleh sebagian masyarakat Indonesia. Pengasapan ikan adalah metode pengolahan ikan yang mengkombinasikan 
proses penggaraman, pemanasan dan pelekatan komponen kimiawi asap. Pengasapan ikan dilakukan untuk mendapatkan ikan dengan rasa, aroma, warna yang khas serta menambah daya awet ikan yang diasapi. Pengsapan ikan dapat dilakukan dengan menggunakan peralatan yang sederhana dan mudah didapat (Darianto et al., 2018). Metode yang digunakan dalam proses pengasapan merupakan salah satu faktor penting yang mempengaruhi kualitas ikan asap (Ghazali et., 2014). Proses pengasapan yang dikenal selama ini terbagi menjadi dua jenis pengasapan, yaitu pengasapan panas dan pengasapan dingin. Namun saat berkembang pula cara pengasapan yang lain yaitu metode pengasapan dengan asap cair (Wibowo, 2020). Ikan terbang atau dalam bahasa lokal mandar dikenal sebagai ikan Tuing - Tuing merupakan salah satu sumberdaya perikanan yang melimpah dan menjadi target utama penangkapan oleh nelayan di Sulawesi Barat. Data Potensi hasil tangkapan ikan terbang oleh nelayan di Sulawesi Barat mencapai 547 ton/Tahun (Dinas Kelautan dan Perikanan Provinsi Sulawesi Barat, 2015). Sumberdaya ikan terbang ini memiliki nilai sosial ekonomi cukup penting di Sulawesi Barat karena sumber pendapatan nelayan, sumber protein, lapangan kerja dalam usaha penangkapan telur, penangkapan ikan, usaha pengeringan dan usaha pengasapan ikan.

Wilayah Somba di Kelurahan Mosso, Kecamatan Sendana, Kabupaten Majene, Provinsi Sulawesi Barat merupakan daerah yang telah dikenal sejak lama memanfaatkan ikan terbang sebagai sumber penghasilan utama masyarakat, salah satunya sebagai pengasap ikan. Produk ikan asap ini digemari karena rasanya yang khas, enak dan gurih. Namun demikian, meskipun sejak dulu masyarakat di Kelurahan Mosso telah bekerja dan berprofesi sebagai pengolah ikan terbang asap namun pendapatan dan kesejahteraan masyarakat di daerah ini masih terbilang masih sangat rendah. Berdasarkan survei lapangan menunjukkan permasalahan yang menyebabkan kelompok usaha pengasapan di Kelurahan Mosso belum berkembang dan kesejahteraannya masih rendah diantaranya adalah kualitas produk yang masih rendah, produk kurang menarik/belum dikemas dengan baik, kemampuan produksi ikan terbang asap ini masih sangat terbatas dan pemasaran yang terbatas untuk komsumsi lokal saja.

Dari segi aspek Produksi, proses produksi yang dilakukan kelompok usaha pengasapan di Kelurahan Mosso masih dilakukan konvesional yaitu ikan terlebih dahulu disiangi dan dibersihkan, kemudian ikan direndam dalam larutan garam, kemudian diletakkan diatas rak pengasapan, ikan diasapi menggunakan bahan bakar kayu, arang dan sabuk kelapa. Ikan terbang asap yang telah matang ini ditandai dengan warna ikan asap yang sudah berwarna kuning kecoklatan. Beberapa kekurangan pada proses produksi ini diantaranya proses produksi yang masih dilakukan tanpa memperhatikan aspek sanitasi (kebersihan produk) dimana pencucian masih dilakukan di lantai, begitupun dengan peralatan produksi yang digunakan masih kurang steril. Hal ini disebabkan masih kurangnya pengetahuan masyarakat tentang tata cara berproduksi yang baik dan benar. Kekurangan yang lain adalah proses pengemasan yang belum ada dan sistem pengasapan yang masih tradisional yang dilakukan pada ruangan terbuka sehingga kurang efisien dimana banyak asap yang terbuang dan menyebabkan pencemaran udara. Selain itu, proses pengasapan ikan terbang yang dilakukan selama ini masih dilakukan secara tradisional, sehingga proses pengasapan yang dilakukan menghasilkan asap yang melimpah dan terhirup oleh para pengasap ikan dan dapat menyebabkan terganggunya kesehatan mata, pernapasan, dan kulit, serta lingkungan di sekitar tempat pengolahan menjadi tercemar asap. Menurut Suroso et al., (2018) pengasapan menggunakan cara tradisional dengan cara pembakaran langsung, memiliki beberapa kelemahan, yaitu kualitas produk yang dihasilkan tidak konsisten, terakumulasinya senyawa berbahaya misalnya tar dan benzopiren pada produk, selain itu juga menyebabkan pencemaran udara, serta efisiensi pengasapan sulit dikontrol.

Dengan adanya teknologi pengasapan ikan ini, asap yang dihasilkan akan dikeluarkan melalui satu saluran pembuangan sehingga dapat mengurangi sebaran asap dan dapat mengurangi dampak buruk bagi kesehatan para pengasap ikan. Olehnya berdasarkan permasalahan tersebut kami selaku bagian dari Sulawesi Barat mencoba melakukan kegiatan pengabdian kepada masyarakat dalam bentuk pendampingan kegiatan penerapan teknologi pengasapan ikan terbang khas mandar guna meningkatkan kesejahteraan dan usaha kelompok ikan terbang asap khas mandar di Kelurahan Mosso, Kecamatan Sendana, Kabupaten Majene, Provinsi Sulawesi Barat.

\section{METODE}

Kegiatan pengabdian kepada masyarakat ini dilaksanakan pada bulan Juni 2020 di Kelurahan Mosso, Kecamatan Sendana, Kabupaten Majene, Provinsi Sulawesi Barat. 
Mitra kelompok yang menjadi sasaran utama pengabdian ini yaitu kelompok usaha pengasapan ikan terbang "Siamasei Lestari" yang terdiri atas 10 anggota.

Metode pelaksanaan pengabdian ini sebagai berikut:

a. Penyuluhan cara produksi yang bagi kelompok usaha pengasapan ikan

Dalam rangka peningkatan kemampuan usaha kelompok pengasapan ikan terbang ini maka dilakukan tahapan perencanaan kegiatan pendampingan yang akan dilakukan, dimana secara teknis antara lain sebagai berikut : kegiatan pendampingan meliputi pemberian materi dan praktek, materi pelatihan ini meliputi tentang tata cara melakukan proses produksi yang baik dan benar dan manajemen usaha. Pelatihan ini dilakukan di dalam ruangan dengan metode diskusi, tanya jawab dan pemaparan materi dengan memanfaatkan media video yang diputar dengan LCD atau lensa proyektor. Sementara itu, kemudian kegiatan praktek dilakukan dengan menerapkan apa telah dipelajari pada saat teori.

b. Pembuatan teknologi alat pengasapan

Pada pengabdian ini dilakukan pembuatan inovasi alat pengasapan secara terkontrol dengan memanfaatkan bahan yang mudah diperoleh yaitu 2 buah drum bekas yang berfungsi sebagai tungku bahan bakar dan oven. Alat ini juga dilengkapi dengan rak tempat meletakkan ikan asap ikan, pipa penghubung sebagai saluran asap dari bahan bakar ke ikan asap, penutup yang dilengkapi dengan cerobong asap. Semua bagian alat ini terbuat dari bahan besi baja yang anti karat. Untuk drum sebelum digunakan juga dilakukan pencatan menggunakan cat anti karat.

\section{HASIL DAN PEMBAHASAN}

\section{a. Penyuluhan dan praktek cara produksi ikan asap yang baik}

Kegiatan penyuluhan cara produksi yang baik dan benar diikuti oleh peserta dari kelompok usaha pengasapan. Kegiatan diawali dengan pemaparan oleh pemateri dilanjutkan praktek oleh anggota kelompok. Kegiatan penyuluhan cara produksi yang baik dan benar dilakukan dengan tujuan agar produksi produk pengasapan ikan terbang yang dilakukan oleh kelompok dilakukan dengan prinsip sanitasi dan hygiene sehingga menghasilkan produk yang berkualitas.

Ikan terbang dan berbagai jenis ikan lainnya dikenal sebagai sebagai bahan makanan yang cepat menjadi busuk (perishable food) sehingga diperlukan tindakan pencegahan yang benar benar menerapkan prinsip-prinsip sanitasi dan higiene. Seblum ikan diasapi tahap pertama adalah persiapan. Persiapan ikan adalah hal utama yang harus diperhatikan dalam pengasapan ikan karena sangat penting untuk mengurangi kerusakan pada produk ikan asap (Sebayang, 2002).

Ikan segar hasil tangkapan nelayan yang baru ditangkap secepat mungkin dilakukan tindakan penyiangan, selanjutnya dilakukan usaha pencucian, yang dikerjakan secara hati-hati. Langkah selanjutnya adalah membuang sumber kontaminan pada ikan seperti isi perut, insang dan seluruh lapisan permukaan kulit; melakukan tindakan pencucian dengan menggunakan air bersih. Pencucian dan penyiangan tersebut dapat mengurangi kandungan mikroba (Soedarto \& Siswanto, 2008). Langkah selanjutnya adalah pemberian garam. Garam digunakan sebagai bumbu dan juga bertindak sebagai daya pengawet. Garam memiliki sifat yang dapat menarik air dari dalam bahan sekaligus cairan sel mikroba sehingga terjadi plasmolisis pada mikroba, serta mencegah terjadinya reaksi autolisis dan membunuh bakteri yang terdapat dalam daging. Ikan selanjutnya siap untuk diasapi.

Selain penyuluhan proses produksi juga dilakukan penyuluhan pengemasan produk. Produk yang dikemas dapat membantu mencegah atau mengurangi kerusakan, melindungi produk yang ada di dalamnya, melindungi dari bahaya pencemaran serta gangguan fisik (gesekan, benturan, getaran). Di samping itu pengemasan berfungsi untuk menempatkan suatu hasil pengolahan atau produk industri agar mempunyai bentuk-bentuk yang memudahkan dalam penyimpanan, pengangkutan dan distribusi. Dari segi promosi wadah atau pembungkus berfungsi sebagai perangsang atau daya tarik pembeli. Proses pengemasan produk ikan terbang dapat dilihat pada Gambar 1.

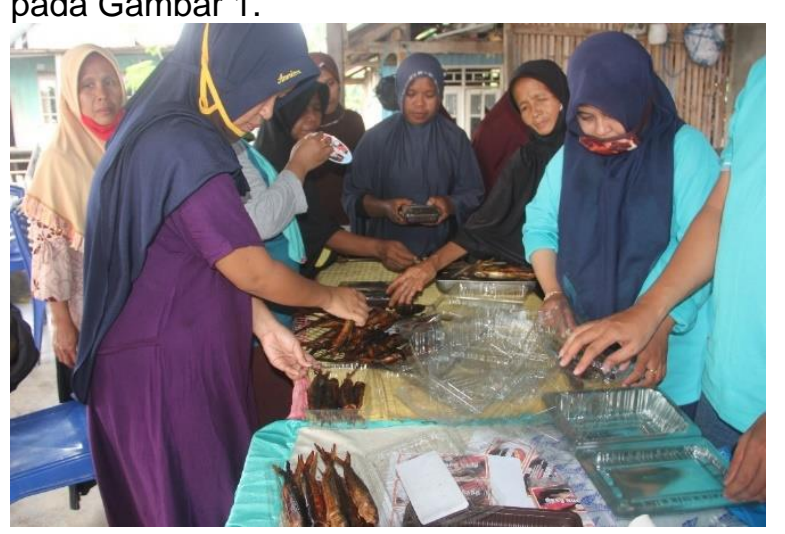

Gambar 1. Proses pengemasan produk ikan terbang 


\section{B. Penerapan teknologi pengasapan ikan terbang}

Pengasapan ikan adalah salah satu cara mengolah dan mengawetkan ikan yang cukup popular di Indonesia. Cara ini dapat dijumpai di berbagai daerah, namun jumlahnya tidak sebanyak produk pengasinan atau pengeringan. Pengasapan dapat menunda proses kemunduran mutu ikan, namun dalam waktu yang tidak terlalu lama, tidak seperti ikan asin atau ikan kering. Tujuan pengasapan pada ikan ada tiga hal. Pertama, mengolah ikan agar siap untuk dikonsumsi langsung. Kedua, memberi cita rasa yang khas agar lebih disukai konsumen. Ketiga, memberikan daya awet melalui pemanasan, pengeringan dan reaksi kimiawi asap dengan jaringan daging ikan pada saat proses pengasapan berlangsung. Menurut Ojeda et al., (2002) tujuan pengasapan yang utama adalah melakukan penetrasi dan deposit asap yang sesuai dalam waktu yang lama, sehingga proses pembusukan makanan akibat aktivitas bakteri dan enzim dapat dihambat. Proses pembakaran kayu akan menghasilkan asap yang mempunyai aktivitas antibakteri yang superior (Braithwaite et al., 2008). Fenol merupakan salah satu indikator kualitas ikan asap, komponen fenol berperan sebagai flavour, bakteriostatik dan antioksidan (Swastawati et al., 2014).

Pembuatan pembuatan dan inovasi teknologi alat pengasapan ikan terbang dapat dilihat pada Gambar 2 dan 3. Inovasi teknologi alat pengasapan, dibuat menggunakan drum bekas sebagai bahan utama alat pengasapan. Penggunaan drum bekas sebagai bahan utama alat pengasapan ini berfungsi sebagai oven dan tungku bahan bakar dan memiliki banyak keuntungan diantaranya biaya yang dikeluarkan oleh kelompok usaha untuk membuat alat pengasapan lebih murah dibanding menggunakan alat pengasapan yang berbentuk lemari pengasapan yang terbuat dari plat-plat besi atau baja, dimana harga 1 buah drum bekas dipasaran hanya berkisar $R p$. 200.000 - Rp. 300.000 sehingga jika dihitunghitung secara keseluruhan untuk membuat 1 buah alat pengasapan ikan dari bahan drum bekas hanya berkisar antara 1.000.000 1.500 .000 rupiah. Dengan biaya yang tergolong relatif murah tersebut keuangan kelompok usaha masyarakat tidak terbebani sehingga dapat dialihkan untuk membeli keperluan alat dan bahan pengasapan kelompok lainnya.

Proses penggunaan alat pengasapan ikan terbang ini adalah ikan terbang yang telah dicuci bersih disusun diatas talenan atau rak pengasapan yang tersusun secara vertikal, kemudian pintu alat pengasapan ikan ditutup rapat dengan tujuan agar asap pembakaran dapat termanfaatkan sempurna di dalam ruang pengasapan (Gambar 4). Daya tampung setiap rak ikan rata-rata sebanyak 350 ekor sehingga dengan tujuh susun rak yang tersedia, alat pengasapan ini mampu menampung 28003000 ekor ikan terbang dalam sekali proses pembakaran. Langkah selanjutnya setelah rak terisi penuh adalah mengisi tungku pembakaran dengan kayu bakar yang selanjutnya dibakar dengan menggunakan korek api. Kayu bakar yang digunakan adalah jenis kayu yang mengandung fenol. Kandungan fenol pada ikan asap akan mempengaruhi kenampakan, bau, rasa, dan daya awet dari ikan asap tersebut (Goulas et al., 2005).

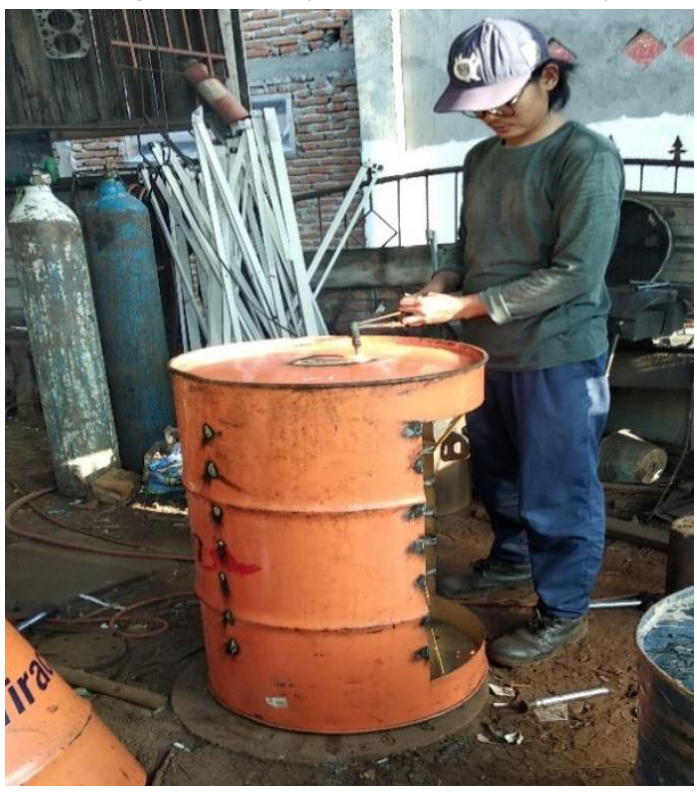

Gambar 2. Proses pembuatan alat pengasapan ikan terbang.

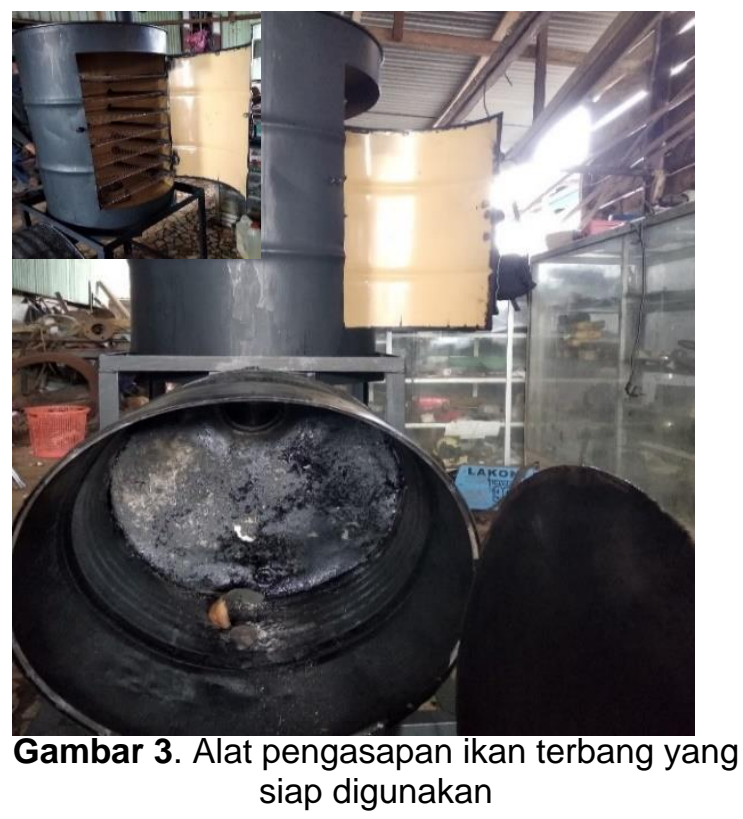




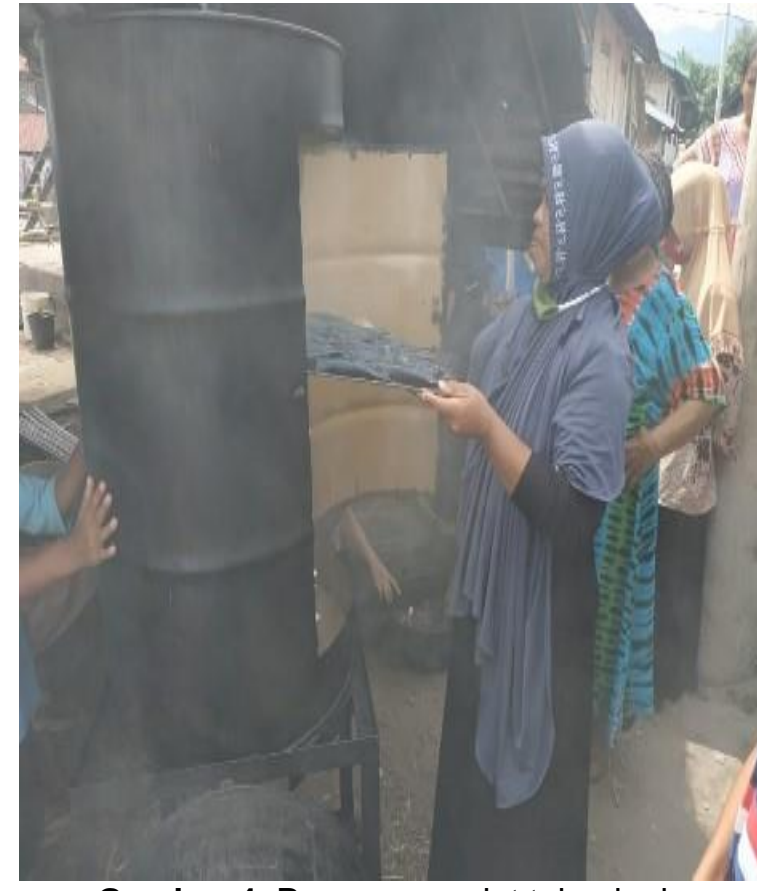

Gambar 4. Pengunaan alat teknologi pengasapan ikan terbang oleh kelompok pengasapan ikan

Ikan yang telah dimasukkan dicek kematangannya setiap 30 menit. Proses pengasapan dilakukan selama kurang lebih satu jam. Beberapa keuntungan dari penggunaan alat ini antara lain 1) Efisiensi penggunaan asap dimana tidak ada asap yang terbuang sehingga ikan terbang menjadi cepat matang dan merata, 2) Kualitas atau kenampakan yang seragam dan warna kekuningan yang lebih menarik, 3) Kuantitas atau jumlah ikan yang diasapi lebih banyak, 4) produk ikan terbang asap dapat matang secara merata tanpa ada bagian yang gosong atau hangus karena semua bagian ikan terkena asap secara keseluruhan 5) Asap terkumpul ke satu arah sehingga tidak menganggu proses pernafasan bagi pengasap maupun bagi masyarakat sekitarnya, 6) menghemat biaya produksi karena efisiensi bahan bakar yang digunakan optimal, 7) produk akhir yang lebih higienis dibanding dengan pengasapan secara terbuka karena proses produksi tidak terkontaminasi oleh debu ataupun udara luar.

\section{SIMPULAN DAN SARAN Simpulan}

Kegiatan penerapan teknologi pengasapan ikan terbang khas mandar sangat bermanfaat dikarenakan meningkatnya pemahaman dan keterampilan masyarakat tentang cara produksi ikan asap yang baik dan adanya alat pengasapan ikan yang dapat meningkatkan usaha ikan terbang seperti meningkat kualitas dan kuantitas ikan terbang yang diasapi.

\section{Saran}

Kegiatan penerapan teknologi pengasapan ikan terbang khas mandar perlu dilanjutkan dan mendapatkan dukungan dari pemerintah setempat karena sangat bermanfaat dalam meningkatkan kuantitas dan kualitas produk untuk meningkatkan kesejahteraan masyarakat.

\section{UCAPAN TERIMA KASIH}

Penulis mengucapkan Terima kasih kepada DRPM Dikti yang telah mendanai kegiatan pengabdian kepada masyarakat ini melalui Program Kemitraan Masyarakat Tahun 2020. Terima kasih selanjutnya kepada Universitas Sulawesi Barat atas fasilitas yang telah diberikan dan kelompok usaha "Siamasei Lestari" yang berkenang menjadi mitra pada kegiatan ini.

\section{DAFTAR RUJUKAN}

Braithwaite, M., Van Vuuren, S. F., \& Viljoen, A. M. (2008). Validation of smoke inhalation therapy to treat microbial infections. Journal of Ethnopharmacology, 119(3), 501-506. https://doi.org/10.1016/j.jep.2008.07.05 0

Darianto, Sutritno, A. (2018). Analisa FaktorFaktor yang Mempengaruhi Proses Pengasapan Pada Mesin Pengasapan Ikan Lele. Journal of Mechanical Engineering, Manufactures, Materials and Energy, 2(2), 56. https://doi.org/10.31289/jmemme.v2i2. 2154

Dinas Kelautan dan Perikanan Provinsi Sulawesi Barat. (2015). Statistik Perikanan Tangkap Provinsi Sulawesi Barat. Mamuju: Dinas Kelautan dan Perikanan Provinsi Sulawesi Barat (Issue).

Ghazali, R.R, Swastawati, F., \& R. (2014). Analisa tingkat keamanan ikan manyung (Arius thalassinus) asap yang diolahdengan metode pengasapan berbeda. Jurnal Pengolahan Dan Bioteknologi Hasil Perikanan, 3, 106112.

Goulas, A. E., \& Kontominas, M. G. (2005). Effect of salting and smoking-method on the keeping quality of chub mackerel (Scomber japonicus): Biochemical and sensory attributes. Food Chemistry, 93(3), 511-520. https://doi.org/10.1016/j.foodchem.200 4.09.040 
Ojeda, M., Bárcenas, P., Pérez-Elortondo, F. J., Albisu, M., \& Guillén, M. D. (2002). Chemical references in sensory analysis of smoke flavourings. Food Chemistry, 78(4), 433-442. https://doi.org/10.1016/S03088146(02)00154-1

Sebayang. (2002). Penerapan Teknologi Pengasapan Ikan Bagi Masyarakat Nelayan. Jurnal Pengabdian Kepada Masyarakat., 8(28), 25-34.

Soedarto, \& Siswanto. (n.d.). Respon Kualitas Bandeng (Chanos chanos) Asap Terhadap Lama Pengeringan. Jurnal Pengolahan Hasil Perikanan Indonesia, 21(1), 42-53. https://www.researchgate.net/publicati on/269630909

Suroso, E., Utomo, T. P., Hidayati, S., \& Nuraini, A. (2018). Pengasapan Ikan Kembung menggunakan Asap Cair dari Kayu Karet Hasil Redestilasi. Jurnal Pengolahan Hasil Perikanan Indonesia, 21(1), https://doi.org/10.17844/jphpi.v21i1.21 261

Swastawati, F., Darmanto, Y. S., Sya'rani, L., Kuswanto, K. R., \& Taylor, K. D. A. (2014). Quality Characteristics of Smoked Skipjack (Katsuwonuspelamis) Using Different Liquid Smoke. International Journal of Bioscience, Biochemistry and Bioinformatics, 4(2), 94-99. https://doi.org/10.7763/ijbbb.2014.v4.3 18

Wibowo. (2020). Industri Pengasapan Ikan. Penebar Swadaya. 